\title{
Olga GRĂDINARU
}

\section{The Civil War and Revolution in Stalinist Films. Cult Films, Evasiveness and Clichés}

\begin{abstract}
Having as a starting point the fact that the Stalinist cinematography played the role of an institution in producing history, the paper proposes analysis of films which tackle the Civil War and the Russian Revolution. Regardless of what films we take into account, whether the cult films of the Soviet cinematography - October (1927) directed by S. Eisenstein or The End of St. Petersburg (1927) directed by V. Pudovkin; some famous adaptations And Quiet Flows the Don (1930) or Chapaev (1934); films inspired by historical figures - Baltic Deputy (1936) and Kotovsky (1942) - we point out to patterns, related to war, time and memory.

The analyzed films reflect a peculiar way of building history, which reveals facets of Stalinist era. On one hand, Stalinist art and rhetoric of the '30s install a temporal hierarchy of high importance for the Soviet Union - designating the October Revolution and Russian Civil War as a crucial moment, a variation of the Great Time in Mircea Eliade's understanding, which was at the beginning, but also the celebrated paradigm of the new history, projected into the future (Clark 2000, 39-40). On the other hand, Socialist Realism established the basis of what proved to be a fruitful system of using renowned heroes from the collective mentality in order to canonize them through ideological fictionalization, historicizing and film adaptation, with all subsequent mythologizing mutations, so that a greater impact on the masses would be acquired'.

Our main concern is to identify the ways in which the following aspects are articulated in films: legitimacy of the Stalinist regime and related myths (great family and variations of "father" and "son" relationship, graveside oaths, picking up the banner, (female) martyr, etc.), representation of The Civit War and Revolution.
\end{abstract}

Keywords: Stalinist cinema and myths, evasiveness and clichés, representation of the Civil War and the Russian Revolution, the Civil War cult.

\section{Introduction}

The main preoccupation of our article is the representation of the Civil War and the Russian Revolution in the Soviet cinematography from historical and synchronic perspectives. The premise of our analysis is constituted by the special status of the Great War, intermingled with the Russian Revolution and Civil War, all playing a great role in shaping
Olga GRĂDINARU

Babeş-Bolyai University

Email: olgagradinaru@gmail.com

EKPHRASIS, 2/2017

Transnational Cinema Dialogues

pp. $120-130$

DOI:10.24193/ekphrasis.18.9

Published First Online: 2017/12/30 
the Soviet mentality (Fitzpatrick 1989, 57-76). All these events, along with the period of Provisional Government after the February Revolution, paved the way for a reevaluation and reconstruction of the Russian culture by grafting socialist ideas on a mentality where religious symbolism was deeply rooted (see some examples of religious mentality and symbols under new political and social circumstances in films on collectivization in Grancea, Grădinaru 2016, 716). That phenomenon shaped the perspective on the Russian past and molded present and future (Hemenway 1999, 6) in a consistent attempt to establish the legitimacy of the Party, and this was achieved partly due to the usage of the Civil War cult, with its heroic narratives and patterns so skillfully used in establishing the World War II cult later (Tumarkin 1994).

Soviet cinema was a key instrument in inducing and popularizing the Civil War cult, the glorious myth and values of the October Revolution, the exemplary figure of the Bolshevik, as opposed to the Menshevik and especially the representatives of the Provisional Government (yet avoiding the complex political background between the February and October Revolution, named dvoevlastie or "two powers"). Our film analysis reveals how scripts, heroes and myths were handled and handed down to the masses in order to ensure the state authority and Stalin's legitimacy as the only true successor of Lenin. At the same time, the cult of the Russian Civil War served as an educational tool, as a catalyst for disseminating political and cultural values (Hartzok 2009, 4) and for inducing the new Soviet identity through the most powerful propaganda weapon - cinematography (Lenin 1970, 579). As E. Dobrenko argues, cinema became the "institution for the production of history" under Stalinism, being responsible for a double transformation of historical events in case of literary adaptations (Dobrenko 2008, 1). Thus, while cinema is, generally speaking, responsible for (an unreliable) reconstruction of reality (Sorlin 1980, 170), the Stalinist cinematography creates the illusion of "reflection," corresponding fully to the nature of Stalinist art (Dobrenko 2008, 4).

\section{Soviet Cult Films about World War 1 and Revolution}

The first two films that we consider to have played a defining role in establishing visual patterns and (re)using revolutionary motives, are masterpieces of renowned Soviet directors - October (1927) directed by S. Eisenstein and The End of St. Petersburg (1927) directed by V. Pudovkin. These cult films were both commissioned by the Bolshevik power to commemorate the tenth anniversary of the October Revolution, thus launching a tradition of films, made-to celebrate Russian Revolution anniversaries.

We may claim that both films establish a canon in representing the First World War and the Revolution: the Provisional Government is presented as abusive follower of the neglectful tsarist policy towards the people, while the Great War is seen as an extension of that policy, with the July Days being its best proof (as several particularly crude scenes in Eisenstein's film demonstrate). The October Revolution is 
seen in opposition to a war that did not concern the Russian people; its true role being to save the Russian peasantry and working class, as well as people living in the close vicinity to the Russian borders. Thus the romantic-heroic representation of the Revolution (and Civil War) ${ }^{2}$ overshadows the importance of the First World War in Soviet filmography, reducing it to clichés images of frozen, starving soldiers in flooded trenches, and of soldiers running towards their death in the background with the foreground dominated by torn barbwire. Thanks to them, World War I is cast in the abject role of enriching the Provisional Government and their entourage and of suppressing people's will to fight for their rights and for the so-called "true Revolution". The most eloquent scenes are to be found in Pudovkin's film: the ideological montage of soldiers running and dying on the battlefield, while members of the high class are running to the stock exchanged to get unjustly enriched. The critical-demystifying vision of the Great War becomes thus obvious, and is contrasted to the image of the October Revolution, presented as expression of the will of the people and the only solution that could restore peace and establish social justice and equality.

Both films are great examples of remodeling the memory of war by mythologyzing the actual events and therefore contributing to the cult of the Civil War with its own system of signs, codes and rituals which, in tune with the main aim of Soviet art, were meant to educate through implementation of socialist mores.

Unlike Eisenstein's October, which foregrounds the masses, Pudovkin's film emphasizes individual-psychological features (Iezuitov 1937, 95). Taking into account that the latter is considered the master of the realist film-portrait, this is not surprising (Kovalov in Tabachnikova 2016, 447). Indeed, while V. Pudovkin's film is deemed a "lyrical epic" in contrast to Alexander Dovzhenko's Arsenal (1929), defined as "philosophic epic", Eisenstein's October is closer to what critics name "journalistic epic" (Iezuitov 1937, 96). It is worth mentioning that Pudovkin's manner of intermingling collective and individual destiny was to be used subsequently by many Soviet directors in their attempts to represent the reality of war and revolution. The main hero of the film, a peasant with no work and no name, or "one among millions" to use the party rhetoric of those years, is a symbol of a new type of relationship with the new times, or to quote famous Soviet critic Neva Zorkaia: "the hero of the revolutionary film, the representative of the working masses, isn't moved by random features and individual character traits, but by the reason of history itself, by the legitimacy of the class struggle" (1969).

In the films mentioned so far, we distinguish a well-pronounced specific Stalinist (both literary and filmic) mythological narrative pattern - that of the relationship between the Bolshevik leader and the novice (or in Katerina Clark's terms "father" and "son"; Clark 2000, 114-124), which sets the hero on the right spiritual-ideological path (even prompts his interior illumination). Moreover, if we are to use Clark's terminology to describe this initiatory route of the hero as the road from a state of spontaneity (stikhiinost') to one of consciousness (soznatel'nost'), it becomes evident that it pre- 
vails in the already mentioned film adaptations -And Quiet Flows the Don (1930) and Chapaev (1934), - as well as Kotovsky (1942) and The Great Dawn (1938). Some variations of the "father-sons" relationship are to be seen in the films Baltic Deputy (1936), We Are from Kronstadt (1936) and in Baltic Sailors (1937), thus furthering the cult of the Civil War by instilling a different type of war memory in people's minds, which replace the traumatic war memories from the Great War or of the Civil War. On the other hand, this strategy of inculcating collective memories had the role of differentiating between the two wars, both bearers of scars and traumas: while the Great War, as we have already pointed out, was imposed by the imperial elites from above (and from the outside by the Allies), and later supported by the Provisional Government and their bourgeois February Revolution (considered not the Revolution of the masses), the Civil War was precipitated by internal reasons, because of the bare necessities of the oppressed people, and thus being a "just and necessary war" for noble causes - social equality and new beginnings: building a "new society" to replace the "old world".

\section{Stalinist Film Adaptations on the Civil War}

Bearing in mind the stringent role Socialist Realism came to play since 1934, Soviet film adaptations under analysis here include not only exemplary works as Chapaev. Whilst Chapaev, the film adaptation of Dmitri Furmanov's auto-biographical novel, directed by the Vasiliev brothers ${ }^{3}$ is considered the finest example of filmic art specific to Socialist Realism (Kaganovsky 2008, 11), the first adaptation of Mikhail Sholokhov's novel And Quiet Flows the Don from 1930 deserves but a mention when compared to its adaptations of later years ${ }^{4}$. And that is due to the fact that the script was largely based on the love affair between Grigory and Aksinya, the main characters, and the directors' perspective was situated outside the class struggle, and seemingly unsupportive of the revolutionary cause. The directors Olga Preobrazhenskaia and Ivan Pravov were excluded from the Association of Contributors to Revolutionary Cinematography shortly after the film release for "favouring small bourgeoisie's tastes specific to spectators unaware of the class struggle" (za potakanie melkoburzhuaznym vkusam klassovo chuzhdykh zritelei). Those were uncertain times after the subsequent reorganization of the centralized Soviet film industry in 1930, which - following the succession of similar attempts in 1924-1925 with Goskino and 1925-1930 with Sovkino - resulted in the creation of Soyuzkino, characterized by the establishment of administrative-bureaucratic units responsible for censorship and review of cinematographic products, liable for the so-called ideologicheskii brak ("ideological waste") (Kenez 1992, 129-130). Both the centralization of the Soviet cinema and the establishment of the Socialist Realism as the accepted method rather than aesthetic style or a school (Hosking 1980, 3) contributed to the simplicity and transparency of the filmic language. These features, combined, resulted in the Soviet "illusion factory" from the 1930s (Lawton 1992, 4) rather than a reliable reflection of the socio-historical reality. 
However, even the not so fortunate film adaptation of M. Sholokhov's novel uses same narrative on the Great War and Revolution: the brave Cossack Grigory is saved by an unlikely comrade - a despised khakhol (Ukrainian) - and initiated in the war and revolutionary subtleties in the hospital. Even the events of the 1905 Revolution are presented from a different angle in Grigory's mind, taking into account the Cossack involvement in repressing that Revolution. Aside from the already classical representation of war, the final scene of the film suggests a new beginning for Grigory, illuminated by the revolutionary truth.

The adaptation of Chapaev is considered the first sign for the institutionalization of the Soviet myth making machine in the way Elena Seniavskaia explained it: taking the heroes recognized by the collective mentality and idealizing them in literary works and film adaptations in order to have a greater impact over the masses (Seniavskaia 1999, 214-216). We have already made reference to the fact that the film uses the specific Stalinist myths, like the initiatory path of the hero (Chapaev) under the guidance of a paternal figure (Commissar Furmanov), the great family, passing the baton from one generation to another. Under Furmanov's guidance, Chapaev evolves from a spontaneous and even outrageous force of nature to a conscientious fighter (soznatel 'nyi boets), worthy of a hero status. Furmanov's civilizing influence extends even over Chapaev's soldiers, putting an end to the robberies and even obtaining Chapaev's support on that matter due to a crafty game.

What we find significant is that the climax of the great Red Army commander transformation process is presented in a symbolical manner by his death in the waters of a river. Death - in both literary and filmic Stalinist texts - has the role of a function in Propp's terms (Propp 2001; see also Grădinaru 2014, 451-462), which ensures the hero's continuity and symbolical multiplication (Clark 2000, 178-182). Heroic death becomes part of the war representation in A. Fadeyev's The Young Guard, directed by the renowned S. Gerasimov (1948), B. Vasiliev's The Dawns Here Are Quiet, directed by S. Rostotskiy (1972), and many others.

The Vasiliev Brothers harness the differences between the Red and White Army, presenting the spatial opposition of their headquarters - wooden cottages, simple and poorly interiors in Chapaev's case, and wealthy interiors that speak of a great aesthetic sense, attention to details in the case of the "white" commanders - and different relations between the commanders and their soldiers (Chapaev is eating, sleeping and singing with his soldiers, while the commanders of the White Army have servants and military inferiors). The visual differences between the two armies on the battlefield are also presented in a humoristic manner, as the exemplary march of the White Army, meant to intimidate the enemy, is scattered with a single machine gun operated by a woman ${ }^{5}$. The spirit of camaraderie between male and female fighters is to be further exploited in other films not only on the subject of the Great War, Civil War and Revolution, but also in films about World War II, providing a pattern in the process of annihilating femininity and replacing it by masculinization which, along with 
emasculation of men, made possible the development of love relations (Kaganovsky $2008,73-74)^{6}$.

It is no wonder that the success of Chapaev (with both authorities and the audience) increased the demand for such films, with a similarly popular positive heroes on a quest to instill social values and provide legitimacy of the regime in the minds of the Soviet citizens. Among those are films, inspired by heroic military epos, like $M y$ iz Kronshtadta (We Are from Kronstadt, 1936, directed by E. Dzigan, script written by V. Vishnevsky), Baltiitsy (Baltic Sailors, 1937, directed by A. Faintsimmer) and Fed'ka [(1936, a film for the young audience, directed by N. Lebedev, known as "children's Chapaev" (Graffy 2010, 84)]. The influence of Chapaev in terms of mythologizing historical facts are to be recognized in films from the so-called Leniniana and Staliniana cycles, more specifically - Lenin v oktiabre (Lenin in October, 1937, edited in 1958, directed by M. Romm), and respectively Velikoe zarevo (The Great Dawn/They Wanted Peace, 1938, directed by M. Chaureli).

\section{Films Inspired by Historical Figures from the Civil War and Revolution}

Among Stalinist films inspired by (mythologized) historical figures, Kotovsky (1942), directed by Aleksandr Faintsimmer, is arguably among the brightest examples, which played a key role in establishing the cult of the Civil War. And this is mostly due to the fact that the main character Grigory Kotovsky combines several successful traits - born and raised in a marginal Soviet Republic, Moldavia, he may be regarded as both a folkloric figure of Romanian origin (khaiduk) and as a spontaneous hero outraged by the social inequality and financial troubles of the peasants. Thanks to a number of trials, overseen by the invariable "father" figure embodied by the enlightened Bolshevik Efim, Kotovsky becomes a conscious Bolshevik leader. His transformation path in several steps includes Efim's death, whose symbolical significance for the Bessarabian ataman's maturity as a new type of leader cannot be underestimated. It is easy to see that both the hero's evolution and its cinematic representation resemble uncannily Chapaev.

The complex phenomenon of "gender confusion" and "gender mutability", encountered in Chapaev (Kaganovsky 2008, 107-109), is to be found in Kotovsky as a condition for the love story between the great military leader and a woman with a (masculine) character, who even saves his life in battle. In line with the then newly developed conventions of Socialist Realism in opposition to naturalism and thus to the somewhat darker sides of human nature, the union between the main hero and the woman (as a life companion) acquires the ideological connotations of socialist nature, presenting their marriage as a new and necessary chapter, which ensures the continuity of the Stalinist "family" (Clark 2000, 183). It is thus relevant that only after being saved by the doctor and only on the battlefield, Kotovsky exclaims that she is "suitable for him" as a partner. In Velikoe zarevo, love blossoms in the same manner be- 
tween the Russian female revolutionary Svetlana and the Georgian soldier (and later Bolshevik commander) Georgy, wounded during the turbulent July Days, thus highlighting the Stalinist myth of the "big family", the unity between various cultures and peoples in their fight for 'self-determination' (samo-opredelenie narodov).

Another specific motif, also of revolutionary origin and present in Kotovsky, is the graveside oath of the great leader, who swears revenge for the innocent Moldavians hung by the merciless German-Romanian invaders. The enemy cruelty establishes an ethnic and moral distinction between the Moldavian identity (artificially created during Soviet times) and the Romanians, through applying specific patterns of war ideology in depicting the Other (Carpentier 2011). The graveside oath appears in We Are from Kronstandt (1936), and a variation of it is to be seen in Baltic Sailors (1937).

The unjust and cruel nature of World War 1, as we have already seen above, is an unwelcomed distraction for all worthy men under the troubled social circumstances throughout the Russian Empire on the eve of the Bolshevik Revolution. On the other hand, the First World War has provided the necessary training for men with a socialist conscience who, when the time comes, could take over the country. In the last scene of the film, we witness Grigory Kotovsky making a speech on an Odessa theatre stage, which announces the demise of the "old Odessa", and proclaims the birth of "our Odessa, a Soviet city for workers".

Another relevant example of a Stalinist film inspired by historic personalities and considered important for the Soviet myth making machine, is Baltic Deputy (1936). It focuses on the figure of a scientist - D. I. Polezhaiev, described in the film as a "great Russian scientist, fighter and thinker". K. A. Timiriazev is the inspiration for the hero of Baltic Deputy - a hypostasis of the new Soviet man, a new type of scientist of great importance for the Soviet agriculture. The Bolshevik attempt to rebuild the world involves scientific mythology and questionable methods known as Michurinism (developed by I. V. Michurin), Lysenkoism (developed by T. D. Lysenko), the myth of rotation in agriculture, the great Stalinist plan of transforming the nature (1948), and constructive geography (Boia 2000, 171-201). The idea of linking the progress of the October Revolution with an open-minded and exceptional biology professor, with direct influence on Soviet agriculture is yet another example of mythologizing history by recasting new scientific findings and breakthroughs as achievements of the newly established Soviet world as opposed to the old, bourgeois and capitalist one.

Moreover, the idea of enlightening the masses is forcefully conveyed in the scene where the old and ailing professor gives a lecture to the sailors on Amur ship about the physiology of plants and the importance of the red color. The scene corroborates the Bolshevik tendency to implement new norms and values, and to inculcate a proper conduct by fostering kul 'turnost' (culturedness) (Hoffmann 2003, 15-19) in order to contribute to the formation of the new Soviet man (Ibid, 45-53).

Baltic Deputy recreates the events and atmosphere of the "red Petrograd" at the end of 1917 along with the tensions and enmities between intellectuals at the dawn of 
the Soviet Union, when a much respected professor publishes an article, which makes public his benevolent views about Bolshevik power. Two types of relations between the "father" and the "son" appear in the filmic text: a successful one (between professor Polezhaiev and his student Mikhail Bocharov, previously exiled to Siberia because of his political views) and a failed one (between the professor and another student Vorobiov, motivated by ambition and lacking the "honorable (Bolshevik) moral character" ${ }^{\prime \prime}$. Other ticklish matters of that period - like the establishment of censorship as a response to unfavorable reviews of Polezhaiev's article in question, - albeit presented in a humorous manner, cannot downplay the ominousness of the newly founded agit-otdel.

Whilst the tensions between Mensheviks and Bolsheviks are only briefly presented in the film, the allegedly strong relationship between Revolution and science is emphasized by such eloquent sentences as: "You [the professor] are the authority of the Revolution, your every word supports the Revolution"; "we have to protect this professor with a young spirit"; "professor Polezhaiev's book is of prime importance for the Revolution". Although present indirectly in the film, V. I. Lenin summons the professor to show his support and admiration, and congratulates him on his birthday.

Professor Polezhaiev is elected deputy of the Petrograd Soviet by sailors of the Red Baltic Fleet and, despite the doctor's advice, he attends an important meeting to give a fiery speech, as he is "honoured to be part of the holy Revolution", "defending the Revolution in his own way, with his pen". Polezhaiev's motivational speech impresses the sailors who are about to fight for Petrograd and Revolution. We find it suggestive that unlike other Soviet films, included in the Leniniana cycle ${ }^{8}$, the film Baltic Deputy doesn't have any scenes with Lenin, whose presence is implied indirectly (a phone call, a letter). Even a much anticipated meeting between Bocharov and Lenin is not part of the film, giving thus the impression that the events in Petrograd of 1917-1918 (as in other Russian cities) were the result of the collective will (including not only rebel sailors, exiled students, but also intelligentsia) and actions, gently steered by the great Bolshevik leader.

\section{Conclusive Remarks}

The establishment of the Civil War cult in Stalinist times may be regarded as the result of various attempts to legitimize the new political leadership and the construction of the Soviet Union. Both the so-called "true Revolution" and the Civil War gained a special place in the temporal hierarchy of the Soviet Union. It becomes a variation of the Great Time as defined by Mircea Eliade as epitomizing the paradisiacal beginnings, but also establishes the celebrated paradigm of the new history as projected into the future (Clark 2000, 39-40). Moreover, in this Stalinist perception of temporality, the present was "sacrificed" and as a result of de-realization, is being shifted into the past, while attempts were made to embed the future into the present (Dobrenko 2008, 5-7). In this way the past is in need of both legitimization and cele- 
bration, and becomes the object of historicisation, ideological fictionalization, museification, and/or film adaptation. This cult of the revolutionary past produced a myriad of literary and filmic masterpieces of Socialist Realism, offering the masses a (didactic) replacement of their social memory with officially ideologized historical narratives. The Stalinist strategy for reconstituting the past used recurrent revolutionary motives of the $19^{\text {th }}$ century, over layering them with new myths and heroes, which resulted in museum-like compositions, featuring a depersonalized past presented with the help of an ideological montage (Ibidem, 7-10).

The Stalinist motif of legacy is obvious in the analyzed films, which offer perspectives on the relationship between generations (the elder "conscious" commissar/ "father" and the "spontaneous" soldier/ sailor/ "son"), and among other aspects the Soviet version of the female emancipation in a romantic-heroic manner. All the mentioned Stalinist motives become clichés in films of the interwar period, contributing to the education of exemplary Soviet citizens and to the instilment of an evasive, selective and ideologically instrumentalized history, especially concerning the troubled events of the Great War, the Russian Revolution(s) of 1917 and the Civil War. Thus the traumatic memory of the Great War seems to be replaced in Stalinist cinematographic productions by the not so traumatic, but rather glorious and victorious period of the supposedly righteous Civil War through a myriad of clichés aiming at rewriting history.

\section{Notes:}

1 N. Ostrovsky's How the Steel Was Tempered, D. Furmanov's Chapaev, A. Fadeyev's The Young Guard, B. Polevoi's A Story About a Real Man are cases of fiction inspired by real men and events, adapted on screen.

2 See the main ways of reflecting war - romantic-heroic and critical-desacralizing in Gheorghiu-Cernat 1983, 46.

3 Georgy and Sergey Vasiliev began working together with the pseudonym "Vasiliev Brothers" (bratia Vasilievy) in 1928. Chapaev was their greatest success, as within a year after its release the film was watched by over 30 million people (Brat 'ia Vasilievy 1983, 545).

4 The 1957-1958 film adaptation was directed by S. Gerasimov; the third adaptation is the 1992 TV-series directed by S. Bondarchuk and montaged by his son in 2006. The fourth adaptation of Sholokhov's novel is the 2015 TV-series, directed by S. Ursulyak.

5 The heroic female presence is notable, especially in the tradition of the revolutionary emancipation present in N. Chernyshevsky's novel What Is to be Done? (1863). See more on the subject in Grădinaru 2011, 1479-1488.

6 There are plenty of other similar examples in the Soviet literature of those years: Fenia in Gladkov's Energy (1938), Olia in Polevoi's A Story About a Real Man (1947) are just several worth mentioning.

7 More hypostases of the relationship "father-son" are present in the film Baltic Sailors (1937): Commissar Timofei Ivanovich and his biological son, his undisciplined friend Zhezlov, another rebel and undisciplined sailor Kolesov. The same couple "mentor-disciple" is pointed out in the film We Are from Kronstandt (1936) in the relationship between commissar Martynov and the nonconformist sailor Artyom. 
8 Two canonical samples of presenting the October Revolution and Russian Civil War as political-cultural campaign are Mikhail Romm's Lenin in October (1937) and Lenin in 1918 (1939), which demonstrate eloquently the Soviet mythologized manner of constructing history.

\section{Works Cited:}

\section{Books}

1. Boia, Lucian. Mitologia ştiințifică a comunismului. București: Humanitas, 2011.

2. Bratia, Vasilievy. Sobranie sochinenii v 3-kh tt. Moskva: Iskusstvo, 1983.

3. Clark, Katerina. The Soviet Novel: History as Ritual. Third Edition, Bloomington and Indianopolis: Indiana University Press, 2000.

4. Dobrenko, Evgeny. Stalinist Cinema and the Production of History: Museum of the Revolution. Translated by Sarah Young. Edinburgh: Edinburgh University Press, 2008.

5. Gheorghiu-Cernat, Manuela. Filmul și armele. Tema păcii și a războiului în filmul European. București: Editura Meridiane, 1983.

6. Graffy, Julian. Chapaev: Kinofiles Film Companion 12. London, New York: I. B. Tauris, 2010.

7. Hoffman, David L. Stalinist Values. The Cultural Norms of Soviet Modernity. Ithaca and London: Cornell University Press, 2003.

8. Hosking, Geoffrey. Beyond Socialist Realism: Soviet Fiction since "Ivan Denisovich". New York: Holmes\&Meier Publishers, 1980.

9. Iezuitov, N. Pudovkin. Puti tvorchestva. Moskva: Iskusstvo, 1937.

10. Kaganovsky, Lilya. How the Soviet Man Was Unmade: Cultural Fantasy and Male Subjectivity under Stalin. Pittsburgh: University of Pittsburgh Press, 2008.

11. Lenin, V. I.. Polnoe sobranie sochinenii. 5-e izdanie v 55 tomakh. Tom 44. Moskva: Izd. Politicheskoi literatury, 1970.

12. Propp, Vladimir. Morfologia volshebnoi skazki. Nauchnaia redaktsia, tekstologicheskii kommentarii I. V. Peshkova. Moskva: Labirint, 2001.

13. Seniavskaia, Elena. Psikhologija voiny v XX veke: istoricheskij opyt Rossii. Moskva: Rosspen, 1999.

14. Sorlin, Pierre. The Film in History: Restaging the Past. Oxford: Basil Blackwell, 1980.

15. Tumarkin, Nina. The Living \& The Dead: The Rise and Fall of the Cult of World War II in Russia. New York: Basic Books, 1994.

\section{Chapters in books}

16. Carpentier, N. "The Ideological Model of War: Discursive Meditations of the Self and the Enemy." Creating Destruction: Constructing Images of Violence and Genocide. Amsterdam: Rodopi, 2011.

17. Fitzpatrick, Sheila. "The Civil War as a Formative Experience." Abbot Gleason, Peter Kenez, and Richard Stites (eds.), Bolshevik Culture: Experiment and Order in the Russian Revolution. Bloomington and Indianopolis: Indiana University Press, 1989.

18. Grancea, Mihaela, Olga Grădinaru. "The Collectivization Process in the Soviet and Romanian Films. A Comparative Perspective." Sorin Radu, Cosmin Budeanca (eds.) 
The Countryside and Communism in Eastern Europe: Perceptions, Attitudes, Propaganda. Wien, Zürich, Münster: LIT Verlag, 2016.

19. Kenez, Peter. "Films of the Second World War." Anna Lawton (ed.), The Red Screen: Politics, Society, Art in Soviet Cinema. London: Routledge, 1992.

20. Kovalov, Oleg. "The Irrational in Russian Cinema: A Short Course." Olga Tabachnikova (ed.), Facets of Russian Irrationalism between Art and Life: Mystery inside Enigma. Leiden, Boston: Brill Rodopi, 2016.

21. Zorkaia, Neva. "V. I. Pudovkin." Istoria sovetskogo kino. 1917-1967, vol. 1. Moskva: Iskusstvo, 1969.

\section{Papers in journals}

22. Grădinaru, Olga. "Scurtă incursiune în problematica personajului pozitiv în proza rusă și sovietică." Studii umaniste și perspective culturale. Cercetări ale doctoranzilor în filologie. Conferință internațională, 14-15 aprilie 2011. Târgu-Mureş: Editura Universităţii “Petru Maior", 2011, pp. 1479-1488.

23. Grădinaru, Olga. "Death Representation in the Soviet Novel of World War 2. A. Fadeyev's The Young Guard." Romanian Journal of Literary Studies, no. 4, 2014. pp. 451-462.

\section{Unpublished studies}

24. Jones Hemenway, Elizabeth. "Telling Stories: Russian Political Culture and Tales of Revolution, 1917-1921." Ph.D. diss. University of North Carolina at Chapel Hill, 1999.

25. Hartzok, Justus Grant. "Children of Chapaev - the Russian Civil War Cult and the Creation of Soviet Identity, 1918-1941." Ph.D. thesis. University of Iowa, 2009. 